\title{
Assessment of Forest Degradation Indices in Mokwa Forest Reserve, Niger State, Nigeria
}

\section{${ }^{1 *}$ JEMINIWA, OR; ${ }^{2}$ JEMINIWA, MS; ${ }^{1}$ TAIWO, DM; ${ }^{2}$ DAUDA, M; ${ }^{1}$ OLAOTI- LAARO, SO}

\author{
${ }^{* 1}$ Forestry Research Institute of Nigeria (FRIN), Ibadan, Oyo State, Nigeria \\ ${ }^{2}$ Southern Guinea Savanna Research Station,(FRIN), Mokwa, Niger State, Nigeria \\ *Corresponding Author Email: jeminiwaoluremi@gmail.com
}

\begin{abstract}
Forest degradation has become a major concern in many countries around the world as it has become one of the most debilitating land use crisis in tropical ecosystems. Hence, this study assessed the forest degradation indices in Mokwa forest reserve. Data were collected using structured questionnaires and field reconnaissance survey. Five settlements were selected in and around the forest reserve namely Mokwa, Jangi, Epa, Kpataki and Tswanle. Data were analyzed using descriptive and inferential statistics. Results showed that farming $(41.7 \%)$ was the main occupation of the people, artisan works (18.8\%) and studentship had the least $(4.2 \%)$. Briquetting of charcoal $(20.8 \%)$ was the highest causes of forest degradation; commercial farming $(18.8 \%)$, overgrazing $(16.7 \%)$ and population increase was the least $(4.2 \%)$. Global warming $(22.9 \%)$ was the major effect of degradation in the study area, soil erosion $(20.8 \%)$ and the least was low rainfall $(9.4 \%)$. Agroforestry practices $(27.1 \%)$ were recorded as the main mitigation measure for reducing degradation in the area. This was followed by Afforestation and enrichment planting (22.9\%), tree planting campaign (18.8\%) and the least was forest conservation and management $(6.3 \%)$. The stepwise multiple regression analysis of the causes with other variables showed that briquetting of charcoal had the highest $\mathrm{R}^{2}(0.88)$, followed by commercial farming $\mathrm{R}^{2}(0.84)$, while population increase had the least $R^{2}(0.57)$. Nevertheless, sustainable empowerment programs are recommended to boost the livelihood of the rural populace and to reduce the overdependence of the people on the forest reserve.
\end{abstract}

\section{DOI: https://dx.doi.org/10.4314/jasem.v24i8.7}

Copyright: Copyright (C) 2020 Jeminiwa et al. This is an open access article distributed under the Creative Commons Attribution License (CCL), which permits unrestricted use, distribution, and reproduction in any medium, provided the original work is properly cited.

Dates: Received: 30 May 2020; Revised: 03 July 2020; Accepted: 05August 2020

Keywords: forest degradation, enrichment planting, livelihood, briquetting.

Forest degradation has become a major concern in many countries around the world. It is one ofthe most debilitating land use crisis in tropical ecosystems. Forest degradation occurs through various processes that impacts negatively on the characteristics of the forest and consequently decrease the value and production of its goods and services. These processes are caused by different disturbance which could either be natural or anthropogenic in form. The natural causes include fire, storm, pests and diseases attack, drought and other natural agents. While anthropogenic forms involved human-induced causes such as tree felling or harvesting, road construction, shifting cultivation, hunting, overgrazing and other hazardous human activities that constitutes threat to the forest ecosystems. Nevertheless, some of these activities aforementioned are categorised under direct causes, while the introduction of exotic species which culminated in the spread of invasive alien species which result in loss of the indigenous species are regarded as indirect human causes (FAO, 2009). Forest degradation has been perceived as a serious environmental, social and economic problem in many countries in the world. Thus, the quantification and intensity is evaluated at varying magnitude by different stakeholders. The International Tropical Timber Organization (ITTO, 2002) opined that about
850 million hectares of tropical forest and forest lands could be degraded in the next three decades. The status of the forest in the early 1990s revealed that, almost $40 \%$ of the earth's land surface had been converted into cropland and permanent pasture. Tropical forest covers 814 million ha, of which 110 million ha is located in Africa, 168million ha in Asia and the pacific, and 536 million ha in Latin America. However, only 25 million ha are exploited in a sustainable way and 11 million ha of tropical forests are conserved with an effective political protection (FAO, 2000).About one third of the earth's land area is covered with forest and nearly $50 \%$ of the total forest land is tropical forest (FAO, 2001). The tropical rain forest harbours a great diversity of plants species which represent many life's forms that provide wide variety of food and other useful materials to the people living in and around the forest (White and Edwards, 2000).The tropical rainforest is a hot, moist biome found near earth's equator. The absence of appropriate forest management and utilization, land tenure policy and lack of compatible forest legislations have resulted to degradation. However, Population growth and the associated expansion of agricultural lands are the current cause of forest degradation around the world (Foley et al., 2011). Forested area in the Amazon Basin, which hosted the largest rainforest on Earth, 
could be reduced with approximately $50 \%$ by 2050 (FAO, 2010) .While most degradation occurs in the tropics, non-tropical forests are likely to suffer new deforestation pressures as the climate warms and areas which were previously too cold become suitable for agriculture (Adedeji and Aiyeloja, 2017).Forests in Nigeria are mostly found in protected areas such as forest reserves and national parks where the residual forests are gradually becoming an island amidst other degraded forest ecosystems in the country. Mokwa forest reserve had been one of the protected areas in Niger state which harbours part of the forest fragments available in the state. Hence, this study examine the forest degradation indices in the forest reserve with a view to document the causes, effects and suggest possible measures to curtail the menace in the reserve. It is anticipated that the results will also provide datum information to reduce degradation in other forest reserves in the state.

\section{MATERIALS AND METHOD}

Study Area: Mokwa forest reserve is located in Mokwa local government area of Niger state, Nigeria. It lies within latitude $9^{0} 12^{\prime}$ and $9^{0} 18^{\prime}$ North and longitude $5^{0} 4^{\prime}$ and $5^{0} 12^{\prime}$ East, covering a land area of about 22.88 square miles. It has a tropical continental climate characterized by a shorter wet season (May to September) and a longer dry season(October to April) with a temperature of $15^{\circ} \mathrm{C}$ to nearly $40{ }^{\circ} \mathrm{C}$ (Adeniji et al., 2015) (Fig. 1).

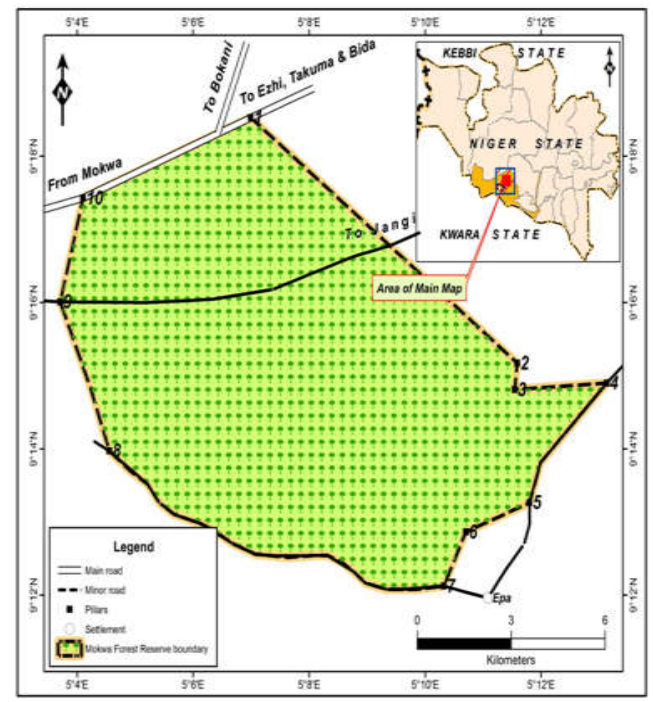

Fig 1: Map of Mokwa forest reserve inset Niger State(Source: Field work, 2019)

Method of Data Collection and Analysis: Structured questionnaires and reconnaissance survey methods were adopted for the study. Five hundred structured questionnaires were used for data collection in the study area. The questionnaires were administered using the method of Diaw et al. (2002). The sampling intensity used is inconformity with the recommendation which stated that a minimum of $10 \%$ sampling intensity could serve as a representative figure for a population less than 500 people. The data collected were analyzed using descriptive and inferential statistics. The descriptive statistics include frequency and percentages, while the inferential statistics involved the use of stepwise multiple regression method.

Stepwise Multiple Regression Analysis: Stepwise multiple regression analysis method was employed to determine the contribution of the causes of degradation to the forest degradation in Mokwa forest reserve (Jeminiwa et al, 2018). For this study, the dependent variable $\mathrm{Y}$ is the qualification and family size of the respondents, while the independent variables 1 - 7 are the causes of forest degradation. Thus, it was expressed statistically as follows:

$$
Y=a+b_{1} X_{1}+b_{2} X_{2} \ldots \ldots \ldots b_{n} X_{n}+e
$$

Where: $\mathrm{Y}=$ Qualification and Family size, $\mathrm{a}=$ Intercept; $b_{1}, b_{n}=$ Parameter estimates; $\mathrm{e}=$ Standard error; $\mathrm{X}_{1}=$ Logging; $\mathrm{X}_{2}=$ Fuelwood extraction; $\mathrm{X}_{3}=$ Overgrazing; $\mathrm{X}_{4}=$ Population increase; $\mathrm{X}_{5}=$

Subsistence farming; $\mathrm{X}_{6}=$ Commercial farming; $\mathrm{X}_{7}=$ Briquetting of charcoal

Sampling Techniques: Five villages were selected in and around the forest reserve and questionnaires were administered using simple random sampling technique. The settlements sampled were Mokwa, Jangi, Epa, Kpataki and Tswanle villages respectively.Reconnaissance survey of the forest reserve was also carried out to observe the present level and status of degradation of the forest reserve. Subsequently, photographs of some degradation activities in the reserve were captured to attest to the current state of the reserve.

\section{RESULTS AND DISCUSSION}

Demographic characteristic of the Respondents in Mokwa forest reserve: The total of 480 questionnaires was retrieved from the respondents in the study area. Some pictures of degradation activities such as farmland, charcoal briquetting heaps, fuelwood and newly felled trees were captured in the forest reserve (plates 1,2, 3 and 4). The data analysis results were as follows: The demographic characteristics of the respondents in the study area revealed that the highest age group of the respondents was 31-40 (27.5\%), followed by $41-50(25.0 \%)$. While, the least group among the respondents was 10-20 (10.0\%). The marital status of the respondents showed that $44.2 \%$ were single, $41.7 \%$ were married and $14.2 \%$ were divorced. It was also discovered that $41.7 \%$ of the respondents had primary education and $40.6 \%$ had no formal education, while $1.0 \%$ as the least had tertiary education. This indicated that the literacy level of the respondents in the study area is low and this informed the high family sizes and perpetual threat to 
biodiversity in the reserve. The family size results showed that, $44.8 \%$ of the respondents had the family size between $1-10$, followed by $11-20(38.5 \%)$ and the least $31-40(6.3 \%)$. The results further indicated that farming was the main occupation in the study area with $41.7 \%$. This agreed to the findings of Olawepo (2010) that most rural populace often depends on farming for their livelihood. While artisan had $18.8 \%$ and student with the least $(4.2 \%)$ and this conformed with observation of Omamurhomu, (2002), that the northern part are the most educationally disadvantaged zone in Nigeria, since most people in this zone attached less value to education (Table 1).

Table 1: Demographic Characteristics of the Respondents in the study area Source: Field Survey, 2019.

\begin{tabular}{lll}
\multicolumn{3}{c}{ Source: Field Survey, 2019.} \\
\hline Variables & $\begin{array}{l}\text { Frequency } \\
(\mathbf{n = 4 8 0 )}\end{array}$ & $\begin{array}{l}\text { Percentage } \\
(\%)\end{array}$ \\
\hline Age Group & & \\
$10-20$ & 48 & 10.0 \\
$21-30$ & 100 & 20.8 \\
$31-40$ & 132 & 27.5 \\
$41-50$ & 120 & 25.0 \\
$\geq 51$ & 80 & 16.7
\end{tabular}

$\begin{array}{lll}\text { Marital Status } & & \\ \text { Single } & 212 & 44.2 \\ \text { Married } & 200 & 41.7 \\ \text { Divorced } & 68 & 14.2\end{array}$

\begin{tabular}{lll}
$\begin{array}{l}\text { Qualification } \\
\text { No formal }\end{array}$ & 195 & 40.6 \\
Primary & 200 & 41.7 \\
Secondary & 80 & 16.7 \\
Tertiary & 5 & 1.0 \\
Family Size & & \\
$1-10$ & 215 & 44.8 \\
$11-20$ & 185 & 38.5 \\
$21-30$ & 50 & 10.4 \\
$31-40$ & 30 & 6.3 \\
Occupation & & \\
Farming & 200 & 41.7 \\
Trading & 60 & 12.5 \\
Hunting & 80 & 16.7 \\
Artisan & 90 & 18.8 \\
Civil servant & 30 & 6.3 \\
Student & 20 & 4.2 \\
\hline
\end{tabular}

Causes of Forest Degradation in Mokwa forest reserve: Observations from the field attested to the fact that forest degradation in the reserve has become a phenomenon that pivoted the livelihood of the people in the study area. Thus, Table 2 indicated that briquetting of charcoal was the major causes of degradation in the study area with $20.8 \%$ (Plate 1). This agreed with the observations of Sedano et al. (2016) that, charcoal production for urban energy consumption is a main driver of forest degradation in sub-saharan Africa. Commercial farming had 18.8\%, which attested to the findings of FAO (2012) that, commercial agriculture is a major causes of deforestation and forest degradation in the tropical forests in the world as evident in the study area (Plate $2)$. While, overgrazing (16.7\%) played devastating role through the transhumances of cattle in the reserve, which often results in loss of undergrowths such as wildlings and saplings with debilitating effects on the regeneration potentials of the forest reserve (Plate 3 ). More also, the branches of the fodder tree species are always pruned to feed the livestock which seldom caused the development of epicomic branches and forest degradation. Fuelwood extraction (15.6\%) also had notable impacts on the reserve as one of the actors of forest cover change in the reserve overtime (Plate 4). This may be due to the fact that remarkable number of the household in the study area relies on fuel wood as a source of heat energy for domestic uses. This is similar to the finding of Sedano et al. (2016), who observed that fuelwood and charcoal were the major energy sources for rural and urban populace in Mozambique. Hence, Achard et al. (2007) opined that deforestation and forest degradation are the principal causes of forest cover change in tropical forests. However, population increase had the least $(4.2 \%)$ and it is believed that increase in population often resulted in corresponding high pressures on adjacent forest land. This conformed to the findings of FAO (2005) that, poverty and overpopulation are the main causes of forest loss in Africa. Thus, Gillet et al. (2016) noted that the forest communal territory is always susceptible to degradation through increased agricultural activities and over dependence on the forest for livelihood.

\begin{tabular}{lll} 
Table 2: Causes of forest degradation in the study area \\
\hline Causes & $\begin{array}{l}\text { Frequency } \\
(\mathbf{n}=\mathbf{4 8 0})\end{array}$ & $\begin{array}{l}\text { Percentage } \\
(\%)\end{array}$ \\
\hline Logging & 50 & 10.4 \\
Fuelwood extraction & 75 & 15.6 \\
Overgrazing & 80 & 16.7 \\
Population increase & 20 & 4.2 \\
Subsistence farming & 65 & 13.5 \\
Commercial farming & 90 & 18.8 \\
Briquetting of charcoal & 100 & 20.8 \\
\hline
\end{tabular}

Source: Field work, 2019.

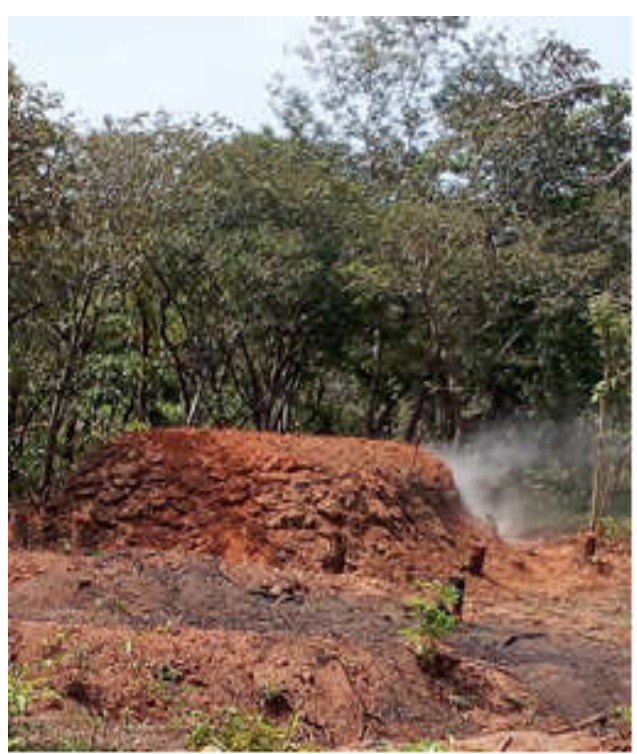

Plate 1. Briquetting of Charcoal in Mokwa forest reserve 


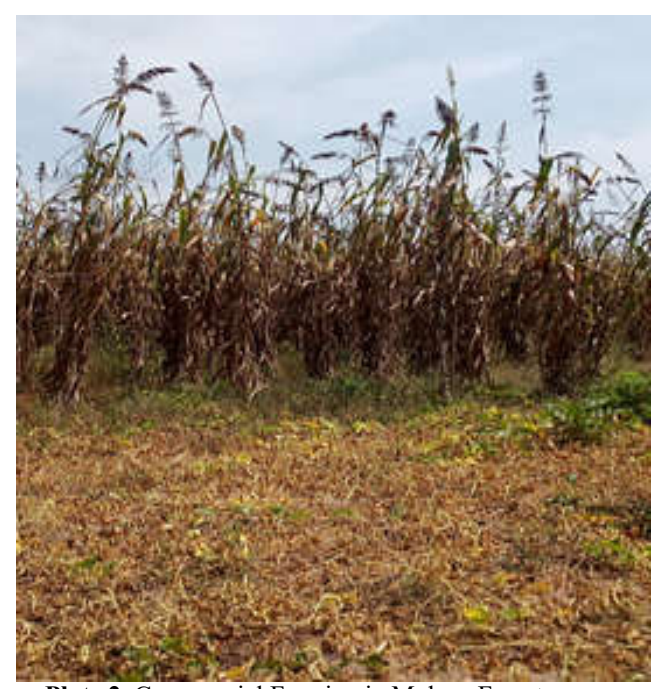

Plate 2. Commercial Farming in Mokwa Forest reserve

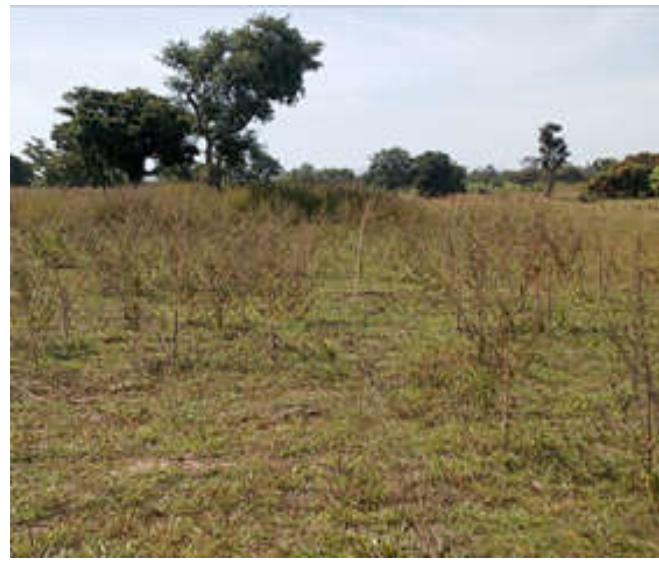

Plate 3. Overgrazing in Mokwa Forest reserve

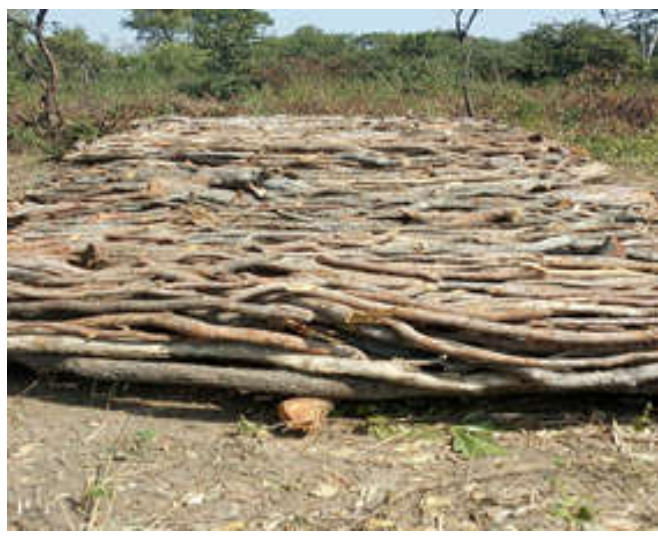

Plate 4. Fuelwood extraction in Mokwa Forest reserve

Effects of forest degradation in Mokwa forest reserve: Forest degradation in the study area have grievous effects on the environments and the nation at large. The effects of forest degradation in the study area (Table 3) revealed that global warming had the highest $(22.9 \%)$ and this may be due to the deforestation of the forest reserve. Deforestation is one of the major drivers of global warming, since it reduces the vegetation cover especially the tree species which play a principal role in carbon sequestration that helps in reducing the atmospheric concentration of greenhouse gases (GHG). Houghton, (2005) noted that over two billion tons of carbon $(\mathrm{CO} 2)$ were emitted into the atmosphere per year as a result of the deforestation of tropical forests. This conformed to the observations of Sumit et al.(2012) who attested that deforestation have a debilitating effects on global atmosphere with consequential impacts on human wellbeing around the world. This was followed by soil erosion effects with $20.8 \%$. This agreed with the observations of Habtamu et al. (2017) who ascertained that soil erosion is one of the grievous effects of forest degradation in tropical zone. Nevertheless, low rainfall is the least effects $(9.4 \%)$ recorded in the study area. The reduction of rainfall in a particular climatic zone has been linked to low vegetation cover traceable to forest degradation and other anthropogenic factors. This was complemented by the observations of Burkett and Stevens-wood (2005) that forest degradation as a key player of global warming which often lead to low vegetation cover and gross reduction of rainfall.

\begin{tabular}{lll}
\multicolumn{3}{l}{ Table 3:Effects of forest degradation in the study area } \\
\hline \multirow{2}{*}{ Effects } & $\begin{array}{l}\text { Frequency } \\
(\mathbf{n = 4 8 0 )}\end{array}$ & $\begin{array}{l}\text { Percentage } \\
(\mathbf{\%})\end{array}$ \\
\hline Global warming & 110 & 22.9 \\
Aridity & 80 & 16.7 \\
Soil Erosion & 100 & 20.8 \\
Loss of wildlife habitat & 60 & 12.5 \\
Loss of biodiversity & 85 & 17.7 \\
Low rainfall & 45 & 9.4 \\
\hline \multicolumn{3}{c}{ Source: Field Survey, 2019. }
\end{tabular}

Mitigation measures for forest degradation in Mokwa forest reserve: There is several mitigation measures recorded in the study area (Table 4). Some of the notable measures suggested were agroforestry practices been the highest with 27.1\%. Food and Agriculture Organization (FAO, 2010) documented agroforestry as a bridge between agriculture and forest conservation practices which often ensure a balance in land-use and forest cover, thereby reducing the gravity of forest degradation in the tropics. It was observed that Afforestation and enrichment planting (22.9\%) were equally suggested as a measure to control forest degradation in the study. These will facilitate the replacement of loss stand and enhance the forest cover, thus promoting forest conservation and management. Tree planting campaign (18.8\%) was another measure given to mitigate the effects of forest degradation in the reserve. This measure conformed to the roles and suggestions of FAWCO (2019) that planting trees inside and outside forest areas will reduce pressure on forests for timber, fodder and fuelwood demands. While the least measure mentioned by the respondents was forest conservation and management $(6.3 \%)$ may be due to poor knowledge about the measures. Adequate education and knowledge about the importance of the forests and the roles in enhancing healthy life will reduce deforestation and forest degradation in the study area. 
Table 4.Mitigation measures for forest degradation in Mokwa forest reserve

\begin{tabular}{lll}
\hline Mitigation measures & $\begin{array}{l}\text { Frequency } \\
(\mathbf{n = 4 8 0 )}\end{array}$ & $\begin{array}{l}\text { Percentage } \\
\mathbf{( \% )}\end{array}$ \\
\hline Afforestation and enrichment planting & 110 & 22.9 \\
Tree planting campaign & 90 & 18.8 \\
Agroforestry practices & 130 & 27.1 \\
Enforcement of forest law and policy & 70 & 14.6 \\
Forest education & 50 & 10.4 \\
Forest conservation and management & 30 & 6.3 \\
\hline \multicolumn{2}{c}{ Source: Field Survey, 2019 }
\end{tabular}

Stepwise Multiple Regression Results for the causes of forest degradation in Mokwa forest reserve: The stepwise multiple regression analysis was used to measure the contribution of each causes to the changes in the vegetation cover in the study area (Table 5). The multiple regression models indicated strong positive relationship between the variables. The result revealed that, briquetting of charcoal $\left(\mathrm{X}_{7}\right)$ had the highest regression coefficients $\left(\mathrm{R}^{2}\right)$ of 0.88 . This was followed by commercial farming $\left(\mathrm{X}_{6}\right)$ with $\mathrm{R}^{2}(0.84)$, overgrazing $\left(\mathrm{X}_{3}\right)$ with $\mathrm{R}^{2}(0.78)$, fuelwood extraction $\left(\mathrm{X}_{2}\right)$ with $\mathrm{R}^{2}(0.70)$, subsistence farming $\left(\mathrm{X}_{5}\right)$ with $\mathrm{R}^{2}$ (0.68). While logging $\left(\mathrm{X}_{1}\right)$ had $\mathrm{R}^{2}(0.60)$ and population increase $\left(\mathrm{X}_{4}\right)$ had the least coefficient of determination $\left(\mathrm{R}^{2}\right)$ of 0.57 respectively. The positive parameter estimates observed were briquetting of charcoal, commercial farming, overgrazing, fuelwood extraction and subsistence farming which connoted their high contribution to the dependent variable. While, logging and population increase were the negative parameter estimates recorded in the study.

\begin{tabular}{|c|c|c|c|c|c|c|}
\hline $\begin{array}{l}\text { Factors of forest } \\
\text { degradation }\end{array}$ & $\begin{array}{l}\text { Parameter } \\
\text { Estimate }\end{array}$ & $\begin{array}{l}\text { Standard } \\
\text { error }\end{array}$ & $\mathbf{R}$ & $\mathbf{R}^{2}$ & $\begin{array}{l}\% \\
\text { Change }\end{array}$ & $\begin{array}{l}\% \\
\text { Cumulative }\end{array}$ \\
\hline Logging & -3.08 & 0.62 & 0.72 & 0.60 & - & 60 \\
\hline Fuelwood extraction & 4.03 & 1.36 & 0.78 & 0.70 & -8 & 70 \\
\hline Overgrazing & 1.46 & 2.13 & 0.88 & 0.78 & -6 & 78 \\
\hline Population Increased & -3.43 & 0.52 & 0.68 & 0.57 & -8 & 57 \\
\hline Subsistence farming & 0.06 & 0.02 & 0.76 & 0.68 & -4 & 68 \\
\hline Commercial Farming & 2.08 & 1.26 & 0.92 & 0.84 & 12 & 84 \\
\hline Briquetting of Charcoal & 2.78 & 1.05 & 0.96 & 0.88 & 24 & 88 \\
\hline
\end{tabular}

Conclusion: Forest degradation has become phenomenon as it has become a major source of livelihood of the people in the study area. The main drivers of degradation in the forest reserve were briquetting of charcoal, commercial farming, overgrazing and fuelwood extraction which depicted the various anthropogenic activities going-on in the area. Nevertheless, sustainable empowerment programs are recommended to the stakeholders to boost the livelihood of the people and to also reduce the overdependence of the people on the forests in the area.

\section{REFERENCES}

Achard, F; De Fries, R; Eva, H; Hansen, M; Mayaux, P; Stibig HJ (2007). Pan-tropical monitoring of deforestation, Env. Res. Letters 2:45-67

Adedeji, GA; Aiyeloja, AA (2017). Exotic versus indigenous and implication for Environmental Forestry Management in the Niger Delta, Nigeria. World Sci. News74: 53-67

Adeniji, OA; Zaccheaus, OS; Ojo, BS; Adedeji, AS (2015). Charcoal Production and Producers' Tree Species Preference in Borgu Local Government of Niger State, Nigeria. J. Energy Tech. and Pol.5: $1-8$.

Burkett, A; Stevens-wood, B. (2005). Effect of low rainfall and browsing by large herbivores on an enclosed savannah habitat in Kenya. Afr. J. Eco. 43(2): 1365-2028.
FAO (2001). The state of food insecurity in the world. Food and Agriculture Organisation (FAO) 3:1-58

FAO (2005). The state of food and agriculture. Food and Agriculture Organisation (FAO) 100:1-92.

FAO, (2000). Food and agriculture organization, Global Forest Resources Assessment. FAO Forestry Paper 140, Rome, Italy, 479pp.

FAO, (2009). Food Agriculture Organisation (FAO) Sustainable Management of Forests and REDD ${ }^{+}$: Negotiations Need Clear Terminology, Info. 4: 815pp.

FAO, (2010). Food and agriculture organization, Global Forest Resources Assessment. Food and Agriculture Organization of the United Nations, Rome. Italy, 340 pp.

FAO, (2012). Drivers of deforestation and forest degradation: A synthesis Report for REDD ${ }^{+}$ policy makers. Kagera Agro-Ecos. 2:1-10.

FAWCO, (2019). Federation of American Women's Clubs Overseas. Three planting campaign as a measure to mitigate forest degradation and climate change. A case study is tree planting campaign in Hage, U.S.A. Bulletin (13) $314 \mathrm{PP}$.

Foley, JA; N. Ramankutty, KA; Brauman, ES; Cassidy, JS; Gerber, Johnston, M; Mueller, ND; O'Connell, C; Ray, DK; West, PC; Balzer, C; Bennett, EM; Carpenter, SR; Hill, J; Monfreda, C; 
Polasky, S; Rockström, J; Sheehan, J; Siebert, S; Tillman, D; Zaks, DPM (2011).Solutions for a cultivated planet. Nature 478: 337-342.

Gillet, P; Cédric, V; Jean-Louis, D; Elisabeth, C; Charlotte, L; Laurens, F (2016). What Are the Impacts of Deforestation on the Harvest of NonTimber Forest Products in Central Africa? Forests 7: 106pp.

Houghton, RA (2005). Tropical deforestation as a source of greenhouse gas emissions. In: Tropical deforestation and Climate change, eds. Moutinho, P. and Schwartzman, S. Amazon Institute for Environmental Research, Belem Brazil 13-20.

ITTO (2002). International Tropical Timber Organisation (ITTO) guidelines for the restoration, management and rehabilitation of degraded and secondary tropical forests. ITTO Policy Development Series, Yokohama, Japan $13: 38-116$.

Jeminiwa, OR; Okanlawon, TF; Taiwo, DM; OlaotiLaaro, SO; Jeminiwa MS (2018). Constraints to Agricultural Productivity in Kainji Lake National Park, Nigeria. Asian J. Res. Agric. and For. 2 (1):1- 9

Mba, EH (2018) Assessment of charcoal production processes and the environmental impact in Kaduna, Nigeria. Res. and Environ. 8 (5):223-231
Olawepo RA. (2010). Determining rural farmers' income: A rural Nigeria experience. J. Afr. Std. and Dev. 2 (3): 99-108.

Omamurhomu, SO (2002): The Educational imbalance between the northern and southern states of Nigeria: A re-direction of educational policies In: Federal Republic of Nigeria, admission statistics (UMED/DE) by states of origin and sex. National Universities Commission in 1997 and 2002, Abuja 52PP.

Sedano, F; Sila, JA; Machoco, R; Meque, CH; Sitoe, A; Ribeiro, N; Anderson, K; Ombe, ZA; Baule, SH; Tucker, CJ (2016). The impact of charcoal production on forest degradation: A case study in Tete, Mozambique. Env. Res. letters 11(9): 10881100 .

Sumit, C; Gosh, SK; Suresh, CP; Dey, AN; Gopal, S (2012). Deforestation: causes, effects and control strategies. Intech open: Creative Commons Attribution 3.0 License, Global perspectives on sustainable forest management 51:958-981

Habtamu, WE; Debela, HF; Serekebirhan, T (2017). Impacts of deforestation on the livelihood of smallholder farmers in Arba Minch Zuria Woreda, Southern Ethiopia. Afr. J. Agric. Res. 12(15) 1293-1305.

White, L., Edwards, A (2000). Conservation research in the African rain forests: a technical hand book. Wild. Cons. Soc. New York 444PP. 